\title{
pH-dependent transcriptional profile changes in iron-deficient Arabidopsis roots
}

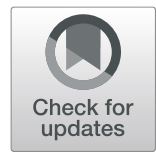

Huei-Hsuan Tsai ${ }^{1}$ and Wolfgang Schmidt $1,2,3^{*}$

\begin{abstract}
Background: Iron is an essential element for plants and abundantly present in most mineral soils. The mobility of iron is, however, dependent on the redox potential and hydrogen activity $(\mathrm{pH})$ of the soil, factors that may limit its availability to plants in particular at alkaline pHs. Iron deficiency triggers pronounced changes in the transcriptional profile of plants, inducing processes that aid in the acquisition, uptake, and translocation of iron. How ambient pH impact the transcriptional iron deficiency response has not yet been elucidated in detail.

Results: Here, we provide an RNA-seq data set that catalogs global gene expression changes of iron-deficient plants grown at either optimal (5.5) or high (7.0) pH. A suite of 857 genes changed significantly and more than twofold in expression; only 54 genes of this suite were also differentially expressed between iron-deficient and ironsufficient plants grown at pH 5.5. Among the high pH-responsive genes, 186 were earlier shown to be responsive to short-term transfer to low pH, 91 genes of this subset were anti-directionally regulated by high and low $\mathrm{pH}$. The latter subset contained genes involved in cell wall organization, auxin homeostasis, and potential hubs of yet undefined signaling circuits. Growing iron-deficient plants at high $\mathrm{pH}$ also modulated the transcriptional iron deficiency response observed at pH 5.5 by compromising the enzymatic reduction of ferric chelates and favoring the production of iron-mobilizing coumarins.
\end{abstract}

Conclusions: It is concluded that ambient $\mathrm{pH}$ is an important determinant of global gene expression which tunes iron acquisition to the prevailing edaphic conditions.

Keywords: Ambient pH, Coumarins, Iron deficiency, Iron uptake, RNA-seq, Transcriptome, Alkaline soil

\section{Background}

Soil $\mathrm{pH}$, i.e. the dynamic equilibrium of $\mathrm{H}^{+}$activity between the soil solution and the negatively charged solid phase, is an important edaphic factor that dictates the availability of mineral nutrients, affects the composition of the microbiome, and determines the composition of plant communities through alterations in the availability of mineral nutrients in the soil [4]. Iron is highly abundant in most soils, but the low mobility of oxidized iron

\footnotetext{
* Correspondence: wosh@gate.sinica.edu.tw

'Institute of Plant and Microbial Biology, Academia Sinica, Taipei 11529, Taiwan

${ }^{2}$ Biotechnology Center, National Chung-Hsing University, Taichung 40227, Taiwan

Full list of author information is available at the end of the article
}

compounds often limits its phyto-availability. In aerated soils, the solubility of iron decreases by a factor of 1000 for each unit increase in $\mathrm{pH}$ between 4 and 9, severely restricting the supply of iron at circumneutral or alkaline conditions [16].

In Arabidopsis and other non-grass species, iron starvation triggers a sophisticatedly regulated response comprising processes which increase the solubilization of recalcitrant soil iron pools, including the acidification of the rhizosphere, secretion of iron-mobilizing compounds, and reductive splitting of ferric chelates with subsequent release and uptake of $\mathrm{Fe}^{2+}$ [11]. Soil $\mathrm{pH}$ has a pronounced effect on the acquisition of iron. In acidic soils, high manganese solubility can interfere with iron uptake and may cause secondary iron deficiency [17]. 
Alkaline conditions, on the other hand, not only restrict the availability of iron, but also compromise the enzymatic reduction of ferric chelates by the plasma membrane-bound reductase FRO2, a central part of the iron uptake mechanism [27]. Restricted mobilization and limited uptake of iron constitute main factors for excluding so-called calcifuge ('chalk-fleeing') plants from habitats with alkaline soil reaction [31].

While the transcriptional response of Arabidopsis to iron starvation has been well explored (e.g. [10, 23, 28]), most studies were conducted at slightly acidic $\mathrm{pH}$ which is optimal for growth, but leaves the influence of alkaline $\mathrm{pH}$ on global gene expression profiles undefined. Knowledge on how ambient $\mathrm{pH}$, in particular neutral or alkaline conditions, affects the transcriptional landscape of iron-deficient plants may aid in understanding the bottlenecks of gene regulation in plants that are not well adapted to soils with limited iron availability. Here, we provide an RNA-seq-based inventory of genome-wide gene expression of roots from iron-deficient Arabidopsis plants grown either at optimal, slightly acidic (5.5), or high (7.0) $\mathrm{pH}$. To mimic the restricted availability of iron at high $\mathrm{pH}$, we provided an iron source of low solubility to plants grown at neutral $\mathrm{pH}$. Alkaline soil reaction aggravates iron deficiency symptoms, but the effect of $\mathrm{pH}$ per se has not yet been clearly distinguished from the response to a lack of iron at a hydrogen activity that is optimal for growth. We believe that the data set provided here allows for gaining valuable insights into the underlying causes of restricted iron uptake, limiting growth in natural or agronomical ecosystems with high $\mathrm{pH}$, and sets the stage for follow up experimentation aimed at identifying novel players involved in the adaptation of plants to the prevailing hydrogen activity.

\section{Results}

Ambient $\mathrm{pH}$ profoundly alters the transcriptomic profile of iron-deficient plants

To investigate the influence of ambient $\mathrm{pH}$ on the global gene expression profile of iron-deficient plants, Arabidopsis seedlings were grown for 14 days on either optimal (5.5) or high $\mathrm{pH}$ (7.0) iron-deficient media, and roots were subjected to transcriptome profiling by RNAseq. Approximately 24 million reads per treatment were captured during sequencing on the Illumina HiSeq 2000 platform, and mapped to the TAIR10 annotation of the Arabidopsis genome.

A flowchart of the experiment is depicted in Fig. 1a. After filtering lowly expressed genes which may not be of biological relevance (expression level in RPKM $<$ the square root of the mean expression value of the whole dataset), a total of 857 genes were defined as being differentially expressed between iron-deficient plants grown at optimal or high $\mathrm{pH}$ media with $\mathrm{a}<0.5$ or $>2$-fold change and a $P$ value of $<0.05$ (Fig. 1a). The expression of a suite of 37 differentially expressed genes (DEGs) was changed more than tenfold (Supplemental Table 1), indicative of robust alterations in transcriptional activity by a relatively subtle change in ambient $\mathrm{pH}$.

To gain insights into the biological significance of the changes in gene expression, a gene ontology (GO) enrichment analysis for the DEGs was conducted using the Singular Enrichment Analysis (SEA) algorithm available on the AgriGO v2.0 toolkit [29], and visualized with the REVIGO Web server [26]. Categorizing the genes that are responsive to high $\mathrm{pH}$ under iron-deficient conditions revealed an overrepresentation of the GO categories 'response to chemical' and 'response to stimulus', indicating that the majority of $\mathrm{pH}$-responsive genes is involved in adapting the plants to environmental conditions (Fig. 1b). Further, the GO category 'secondary metabolism' was significantly enriched. Surprisingly, also genes associated with photosynthesis were overrepresented in the data set, probably mirroring photosynthesis-related processes that are mainly affected in leaves where their expression is altered by high $\mathrm{pH}$ to avoid photo-oxidative damage.

Exposure to high $\mathrm{pH}$ modulated the iron deficiency response of the plants by altering the expression of several key genes functioning in the acquisition of iron. In high $\mathrm{pH}$ plants, FRO2 transcript levels were reduced by approximately $50 \%$ relative to plants grown at pH 5.5 (Supplemental Table 1), matching previous observations of severely compromised in vivo ferric reduction at high $\mathrm{pH}$ [27]. By contrast, expression of the 2-oxoglutaratedependent oxygenase SCOPOLETIN 8-HYDROXYLASE $(\mathrm{S} 8 \mathrm{H})$ was more than threefold induced when plants were grown on high $\mathrm{pH}$. S8H catalyzes the biosynthesis of the iron-mobilizing coumarin fraxetin (7,8-dihydroxy6-methoxy-2H-chromen-2-one) which is secreted into the rhizosphere under iron-deficient conditions, particularly at high $\mathrm{pH}[19,24,25,30]$. Fraxetin mobilizes iron by both reduction and chelation, and may form stable complexes with $\mathrm{Fe}^{2+}[19,30]$. Fraxetin-mediated iron reduction is favored by mildly alkaline $\mathrm{pH}$, compensating for the reduced enzymatic ferric reduction activity under such conditions. Interestingly, expression of another iron-responsive gene in the coumarin biosynthesis pathway, the cytochrome P450 CYP82C4, was completely abolished when plants were grown on high $\mathrm{pH}$ media (Supplemental Table 1). CYP82C4 catalyzes the hydroxylation of fraxetin to form sideretin (5,7,8-trihydroxy-6methoxy-2H-chromen-2-one), a catecholic coumarin with a lower $\mathrm{pH}$ optimum for iron mobilization when compared to fraxetin [19]. It thus appears that ambient $\mathrm{pH}$ can modulate the activity of metabolic enzymes to prioritize the production of specific compounds in order to adapt iron acquisition to the prevailing edaphic 


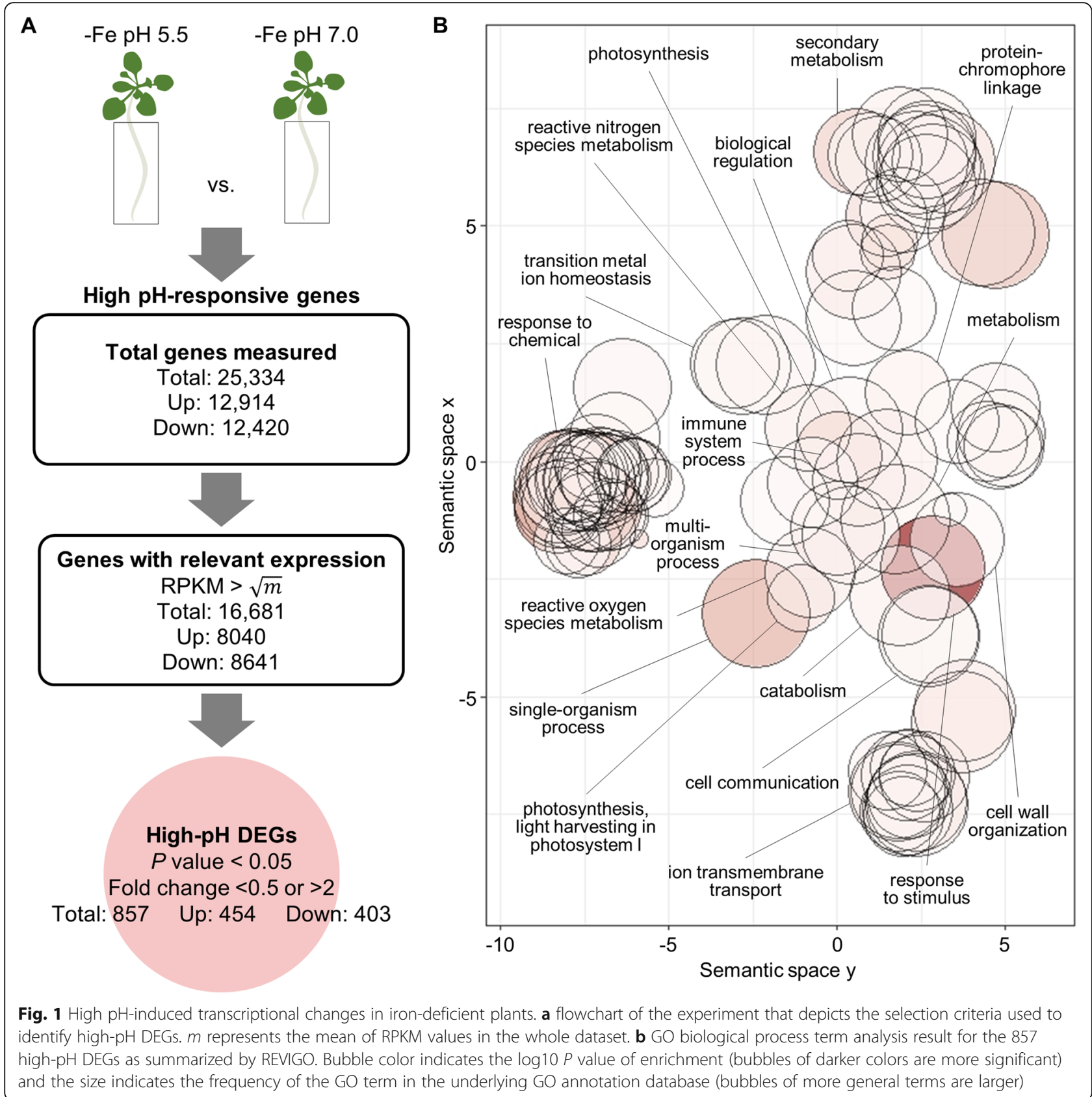

conditions. It is noteworthy that the activity of the two enzymes was altered at the transcriptional level, suggesting that ambient $\mathrm{pH}$ is sensed and relayed to the nucleus to modulate transcript abundance, possibly via recruitment of trans-acting factors. Such a putative $\mathrm{pH}$ sensing system has not been described in plants previously.

\section{Ambient $\mathrm{pH}$ modulates the iron deficiency response}

A suite of circa 250 genes that are differentially expressed between iron-sufficient and iron-deficient plants surveyed at optimal $\mathrm{pH}$ constitute the 'ferrome', a robust shift in the transcriptional profile that induces various iron mobilization strategies and aids in recalibrating cellular iron homeostasis (e.g. [6, 10, 22]). To investigate the effect of a $\mathrm{pH}$ shift on iron-deficient plants, a comparative analysis was conducted between high $\mathrm{pH}$ responsive DEGs and DEGs from an RNA-seq-based profiling of iron-sufficient and iron-deficient plants grown under conditions similar to that of the current study except that plants were grown on $\mathrm{pH} 5.5$ media [22]. A comparison of the high $\mathrm{pH}$-responsive DEGs with the ferrome revealed an overlap of 54 genes 

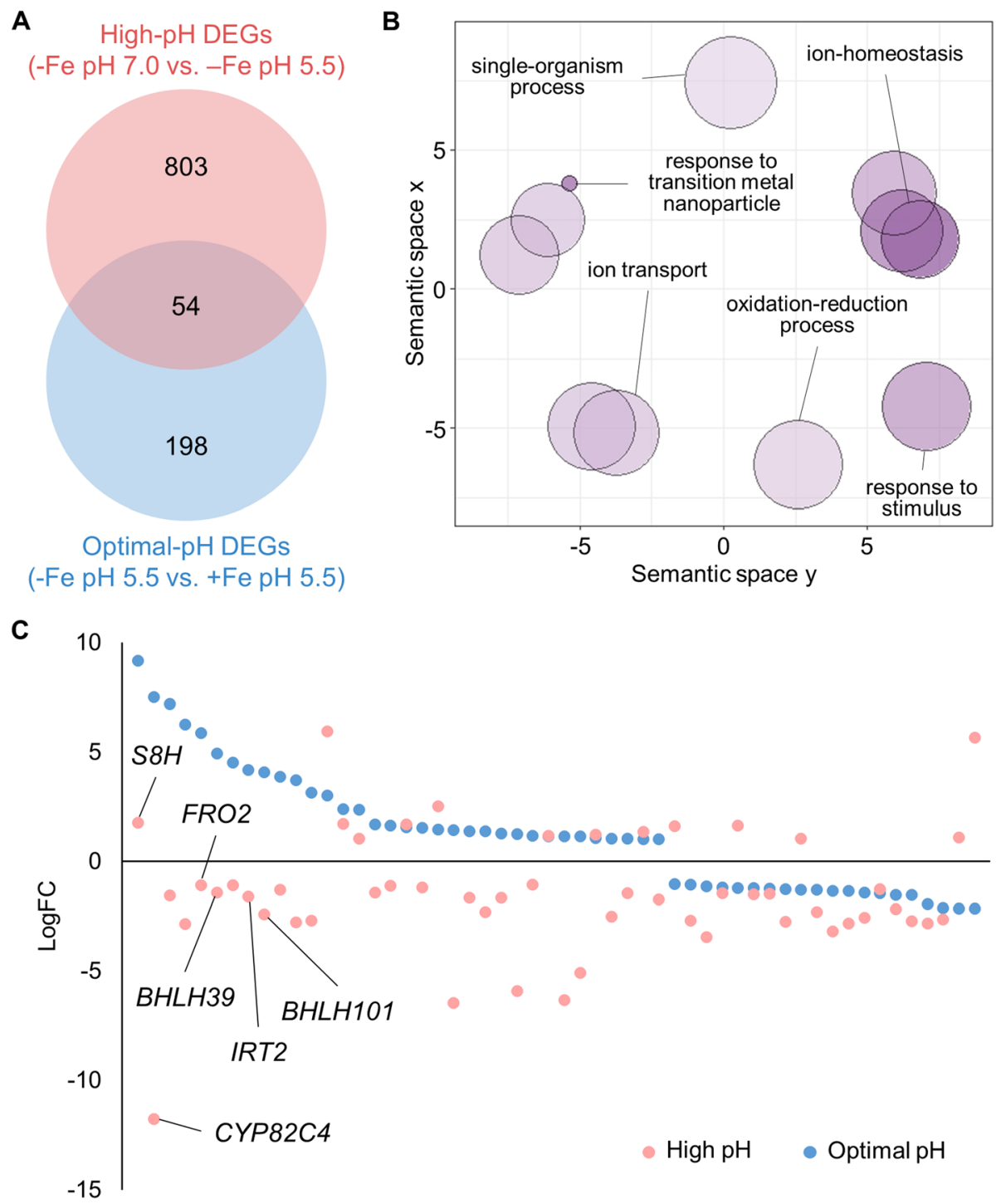

Fig. 2 Comparative analysis between high-pH and optimal pH DEGs. a Venn diagram comparing the DEGs in high-pH and optimal-pH datasets. b GO biological process term analysis result for the common DEGs in (a) as summarized by REVIGO. Bubble color indicates the log $10 P$ value (bubbles of darker color are more significant) and the size indicates the frequency of the GO term in the underlying GO annotation database (bubbles of more general terms are larger). $\mathbf{c}$ Visualization of expression changes of the common DEGs in (a) in both the high-pH and optimal$\mathrm{pH}$ datasets, where the $\mathrm{x}$-axis represents different genes and the $\mathrm{y}$-axis represents the logFC values. Only relevant genes are labeled; refer to Supplemental Table 2 for the complete gene list. Optimal-pH DEGs are from Rodríguez-Celma et al. [22]

(Supplemental Table 2; Fig. 2a). Genes from this overlap were mainly enriched in GO terms associated with 'ion homeostasis' and 'response to transition metal nanoparticle' (Fig. 2b). Interestingly, more than half of the genes are oppositely regulated between plants grown at optimal and high $\mathrm{pH}$. Some $74 \%$ of the genes that were highly upregulated under iron-deficient conditions at optimal $\mathrm{pH}$ were downregulated when plants were grown on high $\mathrm{pH}$ media. This group included several key regulators of iron uptake including the subgroup Ib bHLH proteins $b H L H 39$ and $b H L H 101$ [33], suggesting a direct or indirect involvement of these proteins in the $\mathrm{pH}$ dependent regulation of iron uptake (Fig. 2c). This subset also comprises the iron transporter IRT2 and the oxidoreductase $F R O 2$, which catalyzes the reductive splitting of ferric chelates prior to uptake, the ratelimiting step of iron uptake $[3,7,21,32]$. The reasons for this observation remain to be clarified. It may be speculated that the plant response to high $\mathrm{pH}$ interferes at some nodes with that to Fe deficiency, suggestive of a differential prioritization of different iron uptake strategies at different $\mathrm{pH}$ conditions. 


\section{Exposure of plants to different media $\mathrm{pH}$ uncovers putative nodes in $\mathrm{pH}$ signaling}

A previously conducted transcriptional survey of Arabidopsis roots exposed to low (4.5) $\mathrm{pH}$ medium showed that the expression of a total of 1036 genes was significantly changed after transfer from pH 6.0 [14]. A comparison of this subset to our high $\mathrm{pH}$ data set revealed an overlap of 186 genes. In terms of GO categories, these common DEGs are enriched in the biological functions 'response to chemical', 'immune system process', 'cell wall organization and biogenesis', and 'regulation of hormone levels' (Fig. 3a). A group of 91 genes were antidirectionally regulated by high and low $\mathrm{pH}$ (Table 1 ). The latter list may contain genes that are involved in the perception and transduction of ambient $\mathrm{pH}$. PLANT INTRACELLULAR RAS GROUP-RELATED LRR 8 (PIRL8), a member of a novel class of plant-specific LRR proteins without clearly defined function [5], was found to be highly upregulated in response to high $\mathrm{pH}$ and strongly repressed by low $\mathrm{pH}$ (Table 1). Also, several genes involved in cell wall organization such as the pectin lyase At2g43890, the pectin methylesterase ATPM

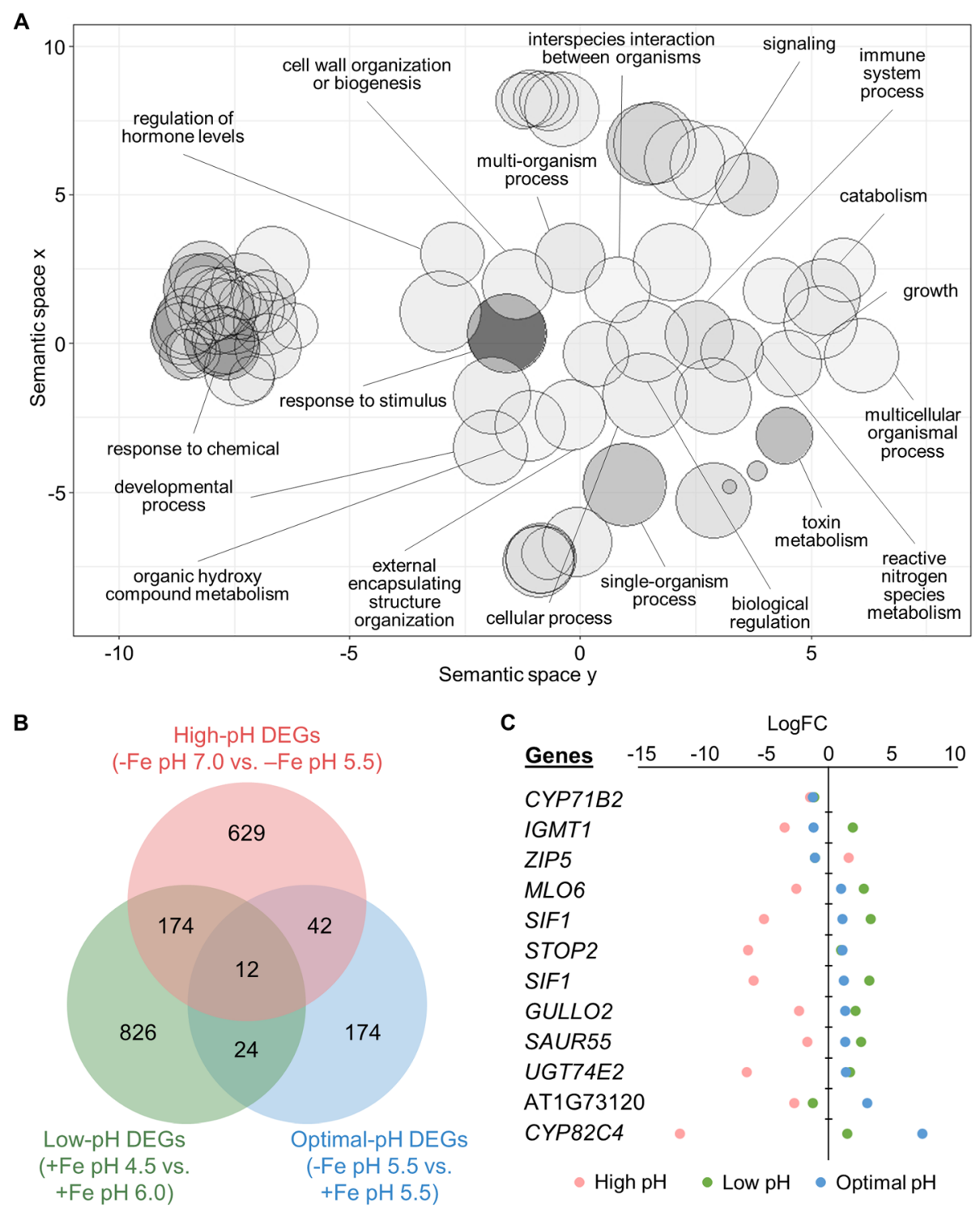

Fig. 3 Effect of pH on the transcriptional profile changes in iron-deficient plants. a GO biological process term analysis result for the 186 common DEGs between high-pH and low-pH datasets as summarized by REVIGO. Bubble color indicates the log $10 P$ value (bubbles of darker color are more significant) and the size indicates the frequency of the $\mathrm{GO}$ term in the underlying $\mathrm{GO}$ annotation database (bubbles of more general terms are larger). b Venn diagram comparing the DEGs in high-pH, optimal-pH, and low-pH datasets. c Visualization of expression changes of the 12 common DEGs in (b). The x-axis represents the logFC values and the $y$-axis represents different genes. Low-pH DEGs are from Lager et al. [14] 
Table 1 Genes with anti-directional regulation by low and high media $\mathrm{pH}$. High pH data derived from the present study, low pH data are taken from Lager et al. [14]

\begin{tabular}{|c|c|c|c|c|c|}
\hline \multirow[t]{2}{*}{ Locus } & \multirow[t]{2}{*}{ Description } & High pH & $\begin{array}{l}\text { Low } \mathrm{pH} \\
(1 \mathrm{~h})\end{array}$ & $\begin{array}{l}\text { Low } \mathrm{pH} \\
(8 \mathrm{~h})\end{array}$ & $\begin{array}{l}\text { High/low } \\
\mathrm{pH} \text { ratio }\end{array}$ \\
\hline & & \multicolumn{4}{|c|}{ Foldchange } \\
\hline AT2G41810 & Imidazolonepropionase & 13.56 & & 0.06 & 214.45 \\
\hline AT4G01630 & EXP17, expansin A17 & 4.32 & 0.10 & & 43.85 \\
\hline AT1G43800 & SAD6, plant stearoyl-acyl-carrier-protein desaturase family protein & 4.26 & & 0.10 & 42.98 \\
\hline AT1G09750 & Eukaryotic aspartyl protease family protein & 2.68 & & 0.07 & 39.09 \\
\hline AT1G33840 & Protein of unknown function (DUF567) & 10.88 & 0.28 & & 38.25 \\
\hline AT4G26050 & PIRL8, plant intracellular ras group-related LRR 8 & 8.22 & 0.23 & & 35.38 \\
\hline AT1G50050 & $\begin{array}{l}\text { CAP (Cysteine-rich secretory proteins, Antigen } 5 \text {, and } \\
\text { Pathogenesis-related } 1 \text { protein) superfamily protein }\end{array}$ & 5.69 & & 0.20 & 28.49 \\
\hline AT2G43890 & Pectin lyase-like superfamily protein & 6.32 & & 0.23 & 26.91 \\
\hline AT5G48430 & Eukaryotic aspartyl protease family protein & 6.61 & 0.30 & & 21.76 \\
\hline AT4G33560 & WIP5, wound-responsive family protein & 4.06 & & 0.27 & 15.26 \\
\hline AT2G43620 & Chitinase family protein & 6.43 & & 0.44 & 14.52 \\
\hline AT1G16510 & SAUR41, SAUR-like auxin-responsive protein family & 3.94 & 0.28 & & 14.13 \\
\hline AT5G45340 & CYP707A3, cytochrome P450, family 707, subfamily A, polypeptide 3 & 3.15 & 0.23 & & 13.62 \\
\hline AT5G60770 & NRT2.4, nitrate transporter 2.4 & 5.60 & & 0.42 & 13.30 \\
\hline AT3G47380 & $\begin{array}{l}\text { ATPMEI11, plant invertase/pectin methylesterase inhibitor } \\
\text { superfamily protein }\end{array}$ & 4.07 & & 0.31 & 13.00 \\
\hline AT3G12830 & SAUR72, SAUR-like auxin-responsive protein family & 3.05 & 0.33 & & 9.33 \\
\hline AT4G10270 & WIP4, WOUND-RESPONSIVE FAMILY PROTEIN & 3.41 & 0.46 & & 7.37 \\
\hline AT5G39890 & PCO2, PLANT CYSTEINE OXIDASE 2 & 2.88 & & 0.43 & 6.78 \\
\hline AT5G15230 & GASA4, GAST1 protein homolog 4 & 2.98 & 0.45 & & 6.58 \\
\hline AT1G05300 & ZIP5, zinc transporter 5 precursor & 3.11 & 0.50 & & 6.25 \\
\hline AT3G10040 & HRA1, HYPOXIA RESPONSE ATTENUATOR1 & 3.07 & & 0.49 & 6.19 \\
\hline AT3G27220 & Galactose oxidase/kelch repeat superfamily protein & 2.77 & & 0.45 & 6.11 \\
\hline AT5G66460 & MAN7, glycosyl hydrolase superfamily protein & 2.18 & & 0.43 & 5.07 \\
\hline AT4G02290 & GH9B13, glycosyl hydrolase 9B13 & 2.35 & & 0.47 & 4.99 \\
\hline AT1G67750 & Pectate lyase family protein & 2.31 & 0.47 & & 4.89 \\
\hline AT1G70710 & CEL1, GH9B1, glycosyl hydrolase 9B1 & 2.24 & 0.49 & & 4.57 \\
\hline AT4G19230 & CYP707A1, cytochrome P450, family 707, subfamily A, polypeptide 1 & 2.14 & & 0.48 & 4.44 \\
\hline AT2G29330 & TRI, TROPINONE REDUCTASE & 0.49 & & 2.28 & 0.22 \\
\hline AT1G35260 & MLP165, MLP-LIKE PROTEIN 165 & 0.47 & & 2.26 & 0.21 \\
\hline AT4G38470 & Dehydrin family protein & 0.47 & & 2.31 & 0.20 \\
\hline AT5G13750 & ZIFL1, ZINC INDUCED FACILITATOR-LIKE 1 & 0.38 & & 2.05 & 0.18 \\
\hline AT4G15610 & Uncharacterized protein family & 0.45 & & 2.45 & 0.18 \\
\hline AT3G21690 & MATE efflux family protein & 0.41 & & 2.31 & 0.18 \\
\hline AT5G66170 & STR18, SULFURTRANSFERASE 18 & 0.41 & & 2.41 & 0.17 \\
\hline AT1G13600 & BZIP58, BASIC LEUCINE-ZIPPER 58 & 0.45 & 2.65 & & 0.17 \\
\hline AT3G14990 & DJ1A, DJ-1 HOMOLOG A & 0.41 & & 2.42 & 0.17 \\
\hline \multirow[t]{2}{*}{ AT1G65310 } & XTH17, XYLOGLUCAN ENDOTRANSGLUCOSYLASE/HYDROLASE 17 & & & & \\
\hline & 0.49 & 2.95 & & 0.17 & \\
\hline AT2G32150 & Haloacid dehalogenase-like hydrolase (HAD) superfamily protein & 0.49 & & 3.13 & 0.16 \\
\hline AT1G55920 & SAT1, SERINE ACETYLTRANSFERASE 1 & 0.36 & 2.56 & & 0.14 \\
\hline
\end{tabular}


Table 1 Genes with anti-directional regulation by low and high media $\mathrm{pH}$. High $\mathrm{pH}$ data derived from the present study, low pH data are taken from Lager et al. [14] (Continued)

\begin{tabular}{|c|c|c|c|c|c|}
\hline \multirow[t]{2}{*}{ Locus } & \multirow[t]{2}{*}{ Description } & High pH & $\begin{array}{l}\text { Low } \mathrm{pH} \\
(1 \mathrm{~h})\end{array}$ & $\begin{array}{l}\text { Low } \mathrm{pH} \\
(8 \mathrm{~h})\end{array}$ & $\begin{array}{l}\text { High/low } \\
\mathrm{pH} \text { ratio }\end{array}$ \\
\hline & & \multicolumn{4}{|c|}{ Foldchange } \\
\hline AT2G39380 & EXO70H2, EXOCYST SUBUNIT EXO70 FAMILY PROTEIN H2 & 0.39 & & 2.78 & 0.14 \\
\hline AT4G38540 & FAD/NAD(P)-binding oxidoreductase family protein & 0.40 & & 2.88 & 0.14 \\
\hline AT3G11340 & UGT76B1, UDP-DEPENDENT GLYCOSYLTRANSFERASE 76B1 & 0.34 & & 2.47 & 0.14 \\
\hline AT1G53990 & GLIP3, GDSL-MOTIF LIPASE 3 & 0.31 & & 2.27 & 0.14 \\
\hline AT1G67810 & SUFE2, SULFUR E2 & 0.32 & 2.35 & & 0.13 \\
\hline AT1G55850 & CSLE1, CELLULOSE SYNTHASE LIKE E1 & 0.42 & & 3.37 & 0.12 \\
\hline AT5G37260 & CIR1, CIRCADIAN 1 & 0.32 & 2.63 & & 0.12 \\
\hline AT3G22370 & AOX1A, ALTERNATIVE OXIDASE 1A & 0.34 & & 2.85 & 0.12 \\
\hline AT1G01720 & ANAC2, ARABIDOPSIS NAC DOMAIN CONTAINING PROTEIN 2 & 0.46 & 4.12 & & 0.11 \\
\hline AT4G30670 & Putative membrane lipoprotein & 0.28 & & 2.65 & 0.10 \\
\hline AT1G43160 & RAP2.6, RELATED TO AP2 6 & 0.33 & & 3.21 & 0.10 \\
\hline AT2G29490 & GSTU1, GLUTATHIONE S-TRANSFERASE TAU 1 & 0.24 & & 2.32 & 0.10 \\
\hline AT1G51420 & SPP1, SUCROSE-PHOSPHATASE 1 & 0.41 & & 4.06 & 0.10 \\
\hline AT1G49570 & Peroxidase superfamily protein & 0.43 & & 4.36 & 0.10 \\
\hline AT1G77450 & ANAC032, NAC DOMAIN CONTAINING PROTEIN 32 & 0.27 & 2.91 & & 0.09 \\
\hline AT1G73260 & KTI1, KUNITZ TRYPSIN INHIBITOR 1 & 0.33 & & 3.75 & 0.09 \\
\hline AT1G80240 & DGR1, DUF642 L-GALL RESPONSIVE GENE 1 & 0.25 & 2.95 & & 0.08 \\
\hline AT3G46230 & HSP17.4, HEAT SHOCK PROTEIN 17.4, & 0.17 & & 2.03 & 0.08 \\
\hline AT1G17180 & GSTU25, GLUTATHIONE S-TRANSFERASE TAU 25 & 0.17 & 2.18 & & 0.08 \\
\hline AT5G24090 & CHIA, CHITINASE A & 0.29 & & 3.94 & 0.07 \\
\hline AT3G01420 & DOX1, PLANT ALPHA DIOXYGENASE 1 & 0.25 & & 3.53 & 0.07 \\
\hline AT5G25460 & DGR2, DUF642 L-GALL RESPONSIVE GENE 2 & 0.38 & & 5.47 & 0.07 \\
\hline AT4G13180 & NAD(P)-binding Rossmann-fold superfamily protein & 0.20 & 3.16 & & 0.06 \\
\hline AT2G29420 & ATGSTU7, GLUTATHIONE S-TRANSFERASE TAU 7 & 0.22 & & 3.64 & 0.06 \\
\hline AT5G61820 & Stress up-regulated Nod 19 protein & 0.17 & & 2.96 & 0.06 \\
\hline AT2G22860 & PSK2, PHYTOSULFOKINE 2 PRECURSOR & 0.23 & & 4.08 & 0.06 \\
\hline AT1G76520 & PILS3, PIN-LIKES 3 & 0.14 & 2.66 & & 0.05 \\
\hline AT5G50760 & SAUR55, SMALL AUXIN UPREGULATED RNA 55 & 0.32 & & 6.13 & 0.05 \\
\hline AT1G05340 & ATHCYSTM1, CYSTEINE-RICH TRANSMEMBRANE MODULE 1 & 0.40 & & 8.31 & 0.05 \\
\hline AT2G46750 & GULLO2, L -GULONO-1,4-LACTONE (L -GULL) OXIDASE 2 & 0.20 & & 4.62 & 0.04 \\
\hline AT1G78340 & GSTU22, GLUTATHIONE S-TRANSFERASE TAU 22 & 0.12 & 2.72 & & 0.04 \\
\hline AT5G49450 & BZIP1, BASIC LEUCINE-ZIPPER 1 & 0.22 & & 6.01 & 0.04 \\
\hline AT5G47990 & $\begin{array}{l}\text { CYP705A5, CYTOCHROME P450, FAMILY 705, SUBFAMILY A, } \\
\text { POLYPEPTIDE } 5\end{array}$ & 0.07 & & 2.05 & 0.04 \\
\hline AT1G02850 & BGLU11, BETA GLUCOSIDASE 11 & 0.30 & & 9.09 & 0.03 \\
\hline AT2G17500 & PILS5, PIN-LIKES 5 & 0.08 & & 2.45 & 0.03 \\
\hline AT5G13080 & WRKY, WRKY DNA-BINDING PROTEIN 75 & 0.20 & & 6.49 & 0.03 \\
\hline AT2G41380 & $\begin{array}{l}\text { S-adenosyl-L-methionine-dependent methyltransferases } \\
\text { superfamily protein }\end{array}$ & 0.06 & 2.09 & & 0.03 \\
\hline AT3G09270 & GSTU8, GLUTATHIONE S-TRANSFERASE TAU 8 & 0.13 & & 5.50 & 0.02 \\
\hline AT1G61560 & MLO6, MILDEW RESISTANCE LOCUS O 6 & 0.18 & & 7.34 & 0.02 \\
\hline AT1G21100 & IGMT1, INDOLE GLUCOSINOLATE O-METHYLTRANSFERASE 1 & 0.09 & & 3.96 & 0.02 \\
\hline
\end{tabular}


Table 1 Genes with anti-directional regulation by low and high media $\mathrm{pH}$. High $\mathrm{pH}$ data derived from the present study, low $\mathrm{pH}$ data are taken from Lager et al. [14] (Continued)

\begin{tabular}{|c|c|c|c|c|c|}
\hline \multirow[t]{2}{*}{ Locus } & \multirow[t]{2}{*}{ Description } & High pH & $\begin{array}{l}\text { Low pH } \\
(1 \mathrm{~h})\end{array}$ & $\begin{array}{l}\text { Low pH } \\
(8 \mathrm{~h})\end{array}$ & \multirow[t]{2}{*}{$\begin{array}{l}\text { High/low } \\
\mathrm{pH} \text { ratio }\end{array}$} \\
\hline & & \multicolumn{3}{|c|}{ Foldchange } & \\
\hline AT4G22610 & Bifunctional inhibitor/lipid-transfer protein/seed storage $2 \mathrm{~S}$ albumin superfamily protein & 0.11 & & 5.37 & 0.02 \\
\hline AT5G48010 & ATTHAS1, THALIANOL SYNTHASE, THALIANOL SYNTHASE 1 & 0.05 & & 3.00 & 0.02 \\
\hline AT2G15490 & UGT73B4, UDP-GLYCOSYLTRANSFERASE 73B4 & 0.05 & 3.06 & & 0.02 \\
\hline AT5G06860 & PGIP1, POLYGALACTURONASE INHIBITING PROTEIN 1 & 0.06 & 4.10 & & 0.01 \\
\hline AT3G13950 & Ankyrin & 0.06 & & 7.14 & 0.01 \\
\hline AT1G17170 & ATGSTU24, GLUTATHIONE S-TRANSFERASE TAU 24 & 0.13 & & 18.19 & 0.01 \\
\hline AT5G22890 & STOP2, SENSITIVE TO PROTON RHIZOTOXICITY 2 & 0.01 & 2.09 & & 0.01 \\
\hline AT1G05680 & UGT74E2, uridine diphosphate glycosyltransferase 74E2 & 0.01 & & 3.45 & 0.00 \\
\hline AT1G51840 & SIF1, STRESS INDUCED FACTOR 1 & 0.03 & & 10.81 & 0.00 \\
\hline AT1G08430 & ALMT1, ALUMINUM-ACTIVATED MALATE TRANSPORTER 1 & 0.03 & & 15.97 & 0.00 \\
\hline AT1G51830 & SIF1, STRESS INDUCED FACTOR 1 & 0.02 & & 9.67 & 0.00 \\
\hline AT4G31940 & CYP82C4, CYTOCHROME P450, FAMILY 82, SUBFAMILY C, POLYPEPTIDE 4 & 0.00 & 2.90 & & 0.00 \\
\hline
\end{tabular}

EI11 and the expansin EXP17 showed a large high pH /low $\mathrm{pH}$ ratio, possibly to compensate compromised cell expansion at alkaline $\mathrm{pH}$. This supposition is supported by a large high $\mathrm{pH} /$ low $\mathrm{pH}$ ratio of the auxin-related genes SAUR41 and SAUR72, which have been associated with the regulation of cell expansion $[13,18]$. High $\mathrm{pH}$ /low $\mathrm{pH}$ ratios below one were observed for STRESS INDUCED FACTOR1 (SIF1), a root-specific, membraneanchored LRR kinase with undefined function [33], the aluminum-activated malate transporter $A L M T 1$, and the Cys2-His2 zinc-finger domain transcription factor SENSITIVE TO PROTON RHIZOTOXICITY 2 (STOP2). The latter two genes are inducible by low $\mathrm{pH}$ stress $[14,12]$; almost complete repression was observed under the present (high $\mathrm{pH}$ ) conditions. Notably, both genes are also induced by phosphate starvation, where ALMT1 and the STOP2 paralog STOP1 repress primary root growth in adaptation to decreased phosphate supply [1, 8]. Also, the auxin efflux carrier family proteins PILS3 and PILS5 [2] were strongly down- and highly upregulated by high and low $\mathrm{pH}$, respectively, suggesting that ambient $\mathrm{pH}$ alters auxin homeostasis. A low high $\mathrm{pH} /$ low $\mathrm{pH}$ ratio was also observed for POLYGALACTURONASE INHIBITING PROTEIN 1 (PGIP1). PGIP1 stabilizes the cell wall under acidic conditions and was found to be dependent on STOP1/STOP2 [12]. Notably, PGIP1, STOP2, ALMT1, SIF1, and the S-adenosyl-L-methionine-dependent methyltransferases superfamily protein At2g41380 are regulated by STOP1 [12].

A subset of 12 genes was responsive to all three conditions under investigation and thus represents genes that are highly responsive to both changes in ambient $\mathrm{pH}$ and iron supply (Fig. 3b, c). This subset comprises CYP82C4 and various regulators such as SIF1, STOP2, and the FIT-regulated F-box/RNI superfamily protein At1g73120. Notably, CYP82C4, which was highly upregulated and downregulated under iron deficiency at optimal and high $\mathrm{pH}$, respectively, was also upregulated at low $\mathrm{pH}$ conditions even when iron is sufficient, suggesting that the expression of CYP82C4 is dictated by external $\mathrm{pH}$ independent of the iron status.

\section{Discussion}

Alkaline soils are thought to aggravate iron deficiency by rendering the acquisition of iron pools more difficult due to decreased iron availability. Our data show that a difference in ambient $\mathrm{pH}$ from 5.5 to 7.0 is causative for considerable differentiation of the global gene expression profile, which goes well beyond simple exacerbation of the iron deficiency response. A relatively large set of genes is anti-directionally regulated by high and low $\mathrm{pH}$, indicating that ambient $\mathrm{pH}$ is translated into transcriptional changes that adapt the plant to the prevailing hydrogen activity, a response that appears to be at least partly elicited by $\mathrm{pH}$ per se and independent of alterations in the availability of essential minerals such as phosphate and nitrate or toxic elements such as aluminum. Moreover, the iron deficiency response as such is modulated by alterations in ambient $\mathrm{pH}$. While FRO2 expression is diminished at circumneutral $\mathrm{pH}$, the production and secretion of iron-mobilizing coumarins is induced by high $\mathrm{pH}$, prioritizing the most effective strategy to mobilize iron from otherwise inaccessible pools.

The transcriptional response of iron-deficient plants grown at high $\mathrm{pH}$ also revealed a pronounced overrepresentation of several categories containing genes that orchestrate the defense responses to pathogens, including 
ERF- and WRKY-type transcription factors, PR proteins, and genes involved in proteolysis, secondary metabolism, and hormone signaling (Supplemental Figure 1). All these responses are much less pronounced in irondeficient plants grown at optimal $\mathrm{pH}$. Exposure to low $\mathrm{pH}$ with sufficient iron supply, on the other hand, elicited a more pronounced pathogen response, indicating $\mathrm{pH}$-dependent prioritization of the responses to pathogen attack and iron starvation. In particular, genes related to signaling were overrepresented under low $\mathrm{pH}$ conditions. This survey shows that ambient $\mathrm{pH}$ considerably modulates the responses to environmental cues by altering the transcriptional landscape of iron-deficient plants to secure and optimize fitness of the plant under a given set of environmental conditions.

\section{Conclusions}

Our transcriptomic survey confirms previous observations that relatively small changes in media $\mathrm{pH}$ can have large impact on gene expression profiles. In addition, we show here that external $\mathrm{pH}$ significantly alters the response to iron deficiency by prioritizing specific, $\mathrm{pH}-$ dependent modules, allowing for a more efficient iron acquisition which is accurately tuned to a given set of edaphic conditions. Furthermore, the current data shed light on the intertwining of various signaling pathways, where external $\mathrm{pH}$ massively influence the decisionmaking process of plants by modulating the hierarchy of the responses to environmental stimuli.

\section{Methods}

Seeds of the Arabidopsis (Arabidopsis thaliana) accession Col-0 were obtained from the Arabidopsis Biological Resource Center (Ohio State University). Plants were grown under sterile conditions in a growth chamber on agar-based media as described by Tsai et al. [30]. The growth medium comprised $5 \mathrm{mM} \mathrm{KNO}_{3}, 2 \mathrm{mM}$ $\mathrm{MgSO}_{4}, 2 \mathrm{mM} \mathrm{Ca}\left(\mathrm{NO}_{3}\right)_{2}, 2.5 \mathrm{mM} \quad \mathrm{KH}_{2} \mathrm{PO}_{4}, 70 \mu \mathrm{M}$ $\mathrm{H}_{3} \mathrm{BO}_{3}, 14 \mu \mathrm{M} \mathrm{MnCl}_{2}, 1 \mu \mathrm{M} \mathrm{ZnSO}, 0.5 \mu \mathrm{M} \mathrm{CuSO}$, $0.01 \mu \mathrm{M} \mathrm{CoCl}$, and $0.2 \mu \mathrm{M} \mathrm{Na}_{2} \mathrm{MoO}_{4}$, supplemented with $1.5 \%(\mathrm{w} / \mathrm{v})$ sucrose, and solidified with $0.4 \%$ Gelrite pure (Kelco). For iron-deficient optimal-pH media, $100 \mu \mathrm{M}$ ferrozine and $1 \mathrm{~g} / \mathrm{L}$ MES were added, and the $\mathrm{pH}$ was adjusted to 5.5 with $\mathrm{KOH}$. For iron-deficient high-pH media, $40 \mu \mathrm{m} \mathrm{FeCl}_{3}$ and $1 \mathrm{~g} / \mathrm{L}$ MOPS were added, and the $\mathrm{pH}$ was adjusted to 7.0 with $\mathrm{KOH}$. Plants were grown on media for $14 \mathrm{~d}$.

For RNA-seq analysis, total RNA was isolated from roots of 14-d-old plants grown under iron-deficient conditions either at optimal (5.5) or high (7.0) pH using the RNeasy Plant Mini Kit (Qiagen). Libraries for RNA-seq were prepared by using the Illumina TruSeq RNA library Prep Kit (RS-122-2001, Illumina) according to the manufacturer's protocol. Briefly, $4 \mu \mathrm{g}$ of total RNA per sample were used for library construction. PolyA RNA was captured by oligodT beads and fragmented when eluted. cDNA was synthesized from fragmented RNA using reverse transcriptase (SuperScript III, Cat. No. 18080-093, Invitrogen) and random primers. Reactions were cleaned up with Agencourt AMPure XP beads (Beckman Coulter Genomics). Libraries were endrepaired, adenylated at the $3^{\prime}$ end, ligated with adapters and amplified according to the TruSeq ${ }^{\mathrm{Tm}}$ RNA Sample Preparation v2 LS protocol. Finally, the products were purified and enriched with 10 cycles of PCR to create the final double-stranded cDNA library. Final libraries were analyzed using Agilent High Sensitivity DNA analysis chip (Cat. no.5067-4626, Agilent) to estimate the quantity and size distribution, and were then quantified by qPCR using the KAPA Library Quantification Kit (KK4824, KAPA). The prepared library was pooled for single-end sequencing using Illumina HiSeq 2500 with 101-bp single-ended sequence read. Transcript abundance was calculated by first mapping reads to the Arabidopsis TAIR10 genome using Bowtie2 [15]. Unmappable reads were mapped to the TAIR 10 genome sequence by BLAT [9]. Read counts were computed using the RackJ package (http://rackj.sourceforge.net/) and normalized using the TMM-quantile method [20]. Normalized read counts were transformed into normalized RPKM values. Z-test was carried out for detecting differentially expressed genes. Two independent biological replicates were performed. RNA-seq data are available at BioProject ID PRJNA664641 (bioprojecthelp@ncbi.nlm.nih.gov).

Gene ontology (GO) enrichment analysis was analyzed using the Singular Enrichment Analysis (SEA) available on the ArgiGO v2.0 toolkit [29]. The analysis was performed using the following parameters: selected species: Arabidopsis thaliana; Reference: TAIR genome locus (TAIR10_2017); Statistical test method: Fisher; Multitest adjustment method: Yekutieli (FDR under dependency); Significance level: 0.05; Minimum number of mapping entries: 5; Gene ontology type: Complete GO. Significantly enriched GO terms were summarized and visualized using REVIGO [26], with a similarity setting of 0.7 and SimRel as the semantic similarity measure. Final figures were plotted in $\mathrm{R}$ (version 3.6.2).

\section{Supplementary information}

Supplementary information accompanies this paper at https://doi.org/10. 1186/s12864-020-07116-6.

Additional file 1: Supplemental Table 1. High-pH DEGs.

Additional file 2: Supplemental Table 2. Common DEGs between high-pH and optimal-pH datasets. 
Additional file 3: Supplemental Figure 1. MapMan visualization of the biotic stress pathway for the DEGs from different transcriptome datasets. Original figure generated based on the referenced data.

\section{Abbreviations}

RNA-seq: RNA-sequencing; GO: Gene onthology; qPCR: Quantitative polymerase chain reaction; RPKM: Reads per kilobase of transcript per million reads mapped

\section{Acknowledgements}

We thank the Genomic Technology Core Laboratory at the Institute of Plant and Microbial Biology (IPMB), Academia Sinica, for preparing RNA-seq libraries for sequencing. We also thank Wen-Dar Lin from the Bioinformatics Core Laboratory at IPMB for bioinformatics support.

\section{Authors' contributions}

H.H.T. contributed to the design of the study, carried out experiments, interpreted data and contributed to the manuscript. W.S. conceived and designed the study, participated in the analysis and interpretation of the data and wrote the manuscript. All authors read and approved the final manuscript.

\section{Funding}

This work was supported by a grant from the Ministry of Science and Technology to W.S. (grant 104-2311-B-001-039-MY3).

\section{Availability of data and materials}

The RNA-seq datasets are available at NCBI Sequence Read Archive under the accession number PRJNA664641.

\section{Ethics approval and consent to participate} Not applicable.

\section{Consent for publication}

Not applicable.

\section{Competing interests}

The authors declare that they have no competing interests.

\section{Author details}

'Institute of Plant and Microbial Biology, Academia Sinica, Taipei 11529, Taiwan. ${ }^{2}$ Biotechnology Center, National Chung-Hsing University, Taichung 40227, Taiwan. ${ }^{3}$ Genome and Systems Biology Degree Program, College of Life Science, National Taiwan University, Taipei 10617, Taiwan.

Received: 25 March 2020 Accepted: 29 September 2020

Published online: 06 October 2020

\section{References}

1. Balzergue C, Dartevelle T, Godon C, Laugier E, Meisrimler C, Teulon JM, et al. Low phosphate activates STOP1-ALMT1 to rapidly inhibit root cell elongation. Nat Commun. 2017;8:1-16.

2. Barbez $E$, Kubeš $M$, Rolčík J, Béziat $C$, Pěnčík $A$, Wang $B$, et al. A novel putative auxin carrier family regulates intracellular auxin homeostasis in plants. Nature. 2012;485(7396):119-22.

3. Connolly EL, Campbell NH, Grotz N, Prichard CL, Guerinot ML. Overexpression of the $\mathrm{FRO} 2$ ferric chelate reductase confers tolerance to growth on low iron and uncovers posttranscriptional control. Plant Physiol. 2003;133(3):1102-10

4. Ellenberg H. Zeigerwerte der Gefäßspflanzen Mitteleuropas. $2^{\text {nd }}$. ed., Scripta Geobotanica 9, Göttingen; 1979.

5. Forsthoefel NR, Cutler K, Port MD, Yamamoto T, Vernon DM. PIRLs: a novel class of plant intracellular leucine-rich repeat proteins. Plant Cell Physiol. 2005;46(6):913-22

6. Grillet L, Lan P, Li W, Mokkapati G, Schmidt W. IRONMAN is a ubiquitous family of peptides that control iron transport in plants. Nat Plants. 2018;4: 953-63.

7. Grusak MA, Welch RM, Kochian LV. Does iron deficiency in Pisum sativum enhance the activity of the root plasmalemma iron transport protein? Plant Physiol. 1990;94(3):1353-7.
8. Godon C, Mercier C, Wang X, David P, Richaud P, Nussaume L, et al. Under phosphate starvation conditions, Fe and Al trigger accumulation of the transcription factor STOP1 in the nucleus of Arabidopsis root cells. Plant J. 2019:99(5):937-49.

9. Kent WJ. BLAT-the BLAST-like alignment tool. Genome Res. 2002;12(4): 656-64.

10. Kim SA, LaCroix IS, Gerber SA, Guerinot ML. The iron deficiency response in Arabidopsis thaliana requires the phosphorylated transcription factor URI. Proc Natl Acad Sci U S A. 2019;116(50):24933-42.

11. Kobayashi T. Understanding the complexity of iron sensing and signaling cascades in plants. Plant Cell Physiol. 2019;60(7):1440-6.

12. Kobayashi $Y$, Ohyama Y, Kobayashi Y, Ito H, luchi S, Fujita M, et al. STOP2 activates transcription of several genes for Al-and low $\mathrm{pH}$-tolerance that are regulated by STOP1 in Arabidopsis. Mol Plant. 2014;7(2):311-22.

13. Kong Y, Zhu Y, Gao C, She W, Lin W, Chen Y, et al. Tissue-specific expression of SMALL AUXIN UP RNA41 differentially regulates cell expansion and root meristem patterning in Arabidopsis. Plant Cell Physiol. 2013;54(4):609-21.

14. Lager IDA, Andréasson O, Dunbar TL, Andreasson E, Escobar MA, Rasmusson AG. Changes in external pH rapidly alter plant gene expression and modulate auxin and elicitor responses. Plant Cell Environ. 2010;33(9): $1513-28$.

15. Langmead B, Salzberg S. Fast gapped-read alignment with bowtie 2. Nat Methods. 2012;9(4):357-9.

16. Lindsay WL. Chemical equilibria in soils. New York; 1979.

17. Marschner H. Mineral nutrition of higher plants 2 nd edition. Great Britain: Academic; 1995.

18. Qiu T, Qi M, Ding X, Zheng Y, Zhou T, Chen Y, et al. The SAUR41 subfamily of SMALL AUXIN UP RNA genes is abscisic acid inducible to modulate cell expansion and salt tolerance in Arabidopsis thaliana seedlings. Ann Bot. 2019:mcz160. https://doi.org/10.1093/aob/mcz160.

19. Rajniak J, Giehl RF, Chang E, Murgia I, von Wirén N, Sattely ES. Biosynthesis of redox-active metabolites in response to iron deficiency in plants. Nat Chem Biol. 2018;14(5):442-50.

20. Robinson MD, Oshlack A. A scaling normalization method for differential expression analysis of RNA-seq data. Genome Biol. 2010;11:R25.

21. Robinson NJ, Procter CM, Connolly EL, Guerinot ML. A ferric-chelate reductase for iron uptake from soils. Nature. 1999;397(6721):694-7.

22. Rodríquez-Celma J, Lin WD, Fu GM, Abadía J, López-Millán AF, Schmidt W. Mutually exclusive alterations in secondary metabolism are critical for the uptake of insoluble iron compounds by Arabidopsis and Medicago truncatula. Plant Physiol. 2013;162(3):1473-85.

23. Schmidt W, Buckhout TJ. A hitchhiker's guide to the Arabidopsis ferrome. Plant Physiol Biochem. 2011;49(5):462-70.

24. Sisó-Terraza P, Luis-Villarroya A, Fourcroy P, Briat JF, Abadia A, Gaymard F, et al. Accumulation and secretion of coumarinolignans and other coumarins in Arabidopsis thaliana roots in response to iron deficiency at high pH. Front Plant Sci. 2016;7:1711.

25. Siwinska J, Siatkowska K, Olry A, Grosjean J, Hehn A, Bourgaud F, et al. Scopoletin 8-hydroxylase: a novel enzyme involved in coumarin biosynthesis and iron-deficiency responses in Arabidopsis. J Exp Bot. 2018;69(7):1735-48.

26. Supek F, Bošnjak M, Škunca N, Šmuc T. REVIGO summarizes and visualizes long lists of gene ontology terms. PLoS One. 2011;6(7):e21800.

27. Susin S, Abadia A, González-Reyes JA, Lucena JJ, Abadia J. The pH requirement for in vivo activity of the iron-deficiency-induced "Turbo" ferric chelate reductase (a comparison of the iron-deficiency-induced iron reductase activities of intact plants and isolated plasma membrane fractions in sugar beet). Plant Physiol. 1996:110(1):111-23.

28. Thimm O, Essigmann B, Kloska S, Altmann T, Buckhout TJ. Response of Arabidopsis to iron deficiency stress as revealed by microarray analysis. Plant Physiol. 2001;127(3):1030-43.

29. Tian T, Liu Y, Yan H, You Q, Yi X, Du Z, et al. agriGO v2.0: a GO analysis toolkit for the agricultural community. Nucleic Acids Res. 2017;45(W1):122-9.

30. Tsai HH, Rodríguez-Celma J, Lan P, Wu YC, Vélez-Bermúdez IC, Schmidt W. Scopoletin 8-hydroxylase-mediated fraxetin production is crucial for iron mobilization. Plant Physiol. 2018:177(1):194-207.

31. Tyler G. Soil chemical limitations to growth and development of Veronica officinalis L. and Carex pilulifera L. Plant Soil. 1996;184:281-9.

32. Vert G, Grotz N, Dédaldéchamp F, Gaymard F, Guerinot ML, Briat JF, et al. IRT1, an Arabidopsis transporter essential for iron uptake from the soil and for plant growth. Plant Cell. 2002;14(6):1223-33. 
33. Yuan Y, Wu H, Wang N, Li J, Zhao W, Du J, et al. FIT interacts with AtbHLH38 and AtbHLH39 in regulating iron uptake gene expression for iron homeostasis in Arabidopsis. Cell Res. 2008;18(3):385-97.

\section{Publisher's Note}

Springer Nature remains neutral with regard to jurisdictional claims in published maps and institutional affiliations.

Ready to submit your research? Choose BMC and benefit from:

- fast, convenient online submission

- thorough peer review by experienced researchers in your field

- rapid publication on acceptance

- support for research data, including large and complex data types

- gold Open Access which fosters wider collaboration and increased citations

- maximum visibility for your research: over $100 \mathrm{M}$ website views per year

At $\mathrm{BMC}$, research is always in progress. 